\title{
STUDY OF RELATIONSHIP BETWEEN SP1 POLYMORPHISM IN THE COLLAGEN TYPE I ALPHA -1 (COLIA1) GENE AND OSTEOPROSIS IN PATIENTS WITH BETA-THALASSEMIA.
}

\author{
Naglaa Ali Khalifa, Mervat AbdAlla Hesham, Nadia Ahmad Elbaz, Alaa Abdelmoati Omran, Doaa Metwaly \\ AbdElmonem. \\ Clinical Pathology and pediatrics Medicine Departments, Faculty of Medicine, Zagazig University; Egypt.
}

**Corresponding Author

DoaaM. AbdElmonem

Tel. No: 01226391406

\section{ABSTRACT}

Background:-Osteoporosis is an important cause of morbidity in patients with $\beta$-thalassemia. The pathogenesis of reduced bone mineral density (BMD) is multifactorial. A range of genetics factors have been implicated in patients with osteoporosis. Polymorphism at the Sp1 binding site of the collagen type I A 1(COLIA1) gene is thought to be an important factor in development of osteoporosis.

Objective:-is to study the relationship between SP1 polymorphism in the collagen type 1 alpha 1 gene and the development of osteoporosis in patients with Beta thalassemia.

Methods:-A total of 40 patients with $\beta$-thalassemia( 21 females \&19 males)aged 6-18 yearsand 40 healthy subjects cross matched with age and sex. Serum osteocalcin, serum alkaline phosphatase, calcium and DEXA were examined in all patients. The COLIAI Splgenotypes (SS, Ss, ss) were measured by digestion using restriction enzyme (Bal1) of DNA amplified by the polymerase chain reaction (PCR).

Results:-SS (G/G) genotype in $\beta$-thalassemia major was $30.7 \%$ and in $\beta$ thalassemia intermedia was $49.4 \%$ and the $\mathrm{Ss}(\mathrm{G} / \mathrm{T})$ genotype in $\beta \mathrm{T}$ Major was $55.63 \%$ and in $\beta \mathrm{T}$ intermedia was $50.6 \%$, the ss genotype (T/T) type in $\beta \mathrm{TM}$ was $13.67 \%$ only. The difference was statistically significant $(\mathrm{p}=0.040)$. There was highly significant difference between thalassemia major and thalassemia intermedia compared to control group as regard Ca, OC, ALP and DEXA $(\mathrm{P}=0.000)$.

Conclusions:-Detection base substitutions at the $\mathrm{Sp} 1$ binding site on the COLIA1 gene in early years considering an important role in preventing osteoporosis in children with beta -thalassemia.and early mangment of these patients.

Key words:

Beta-thalassemia, COLIA1,osteoprosis.

\section{INTRODUCTION}

B eta thalassemia syndromes are a group of genetic diseasesfamous by a genetic defect in the formation of $\beta$-globin chains. This genetic deficiency leads to marked transfusiondependent anemia in the homozygous type of beta thalassemia (thalassemia major) while in the heterozygous type of the $\beta$-thalassemia (thalassemia minor) leads to mild to moderate microcytic anemia. Patients with clinical severity of the disease lie between thalassemia major and thalassemia minor are defined as thalassemia intermedia. Many different genotypes are associated with thalassemia intermedia [1].

In spite of the improved treatment of the hematologic disorder and its complications, $\beta$ thalassemia patients exhibit an unbalance in bone mineral turnover with increased resorptive rates and suppression of osteoblast activity, resulting in diminished bone mineral density (BMD) more evident in the lumbar spine [2].

Osteoporosis is a debilitating bone disease which detected by a decrease low bone mass 
and density and results inhigh risk of fracture. In low bone mass, together environmental and polygenic factors are the cause of osteoporosis [3].

Many researches detected that the collagen one gene genotype diagnoses bone fracture by ways that are partly not dependent of bone mineral density [4]. There is high risk fracture in relation to SP1 polymorphism although of mild relation with bone mineral density [5].

Polygenic factors has an important role in the development of osteoporosis, containing variability in many genes for example collagen type I alpha 1 (COLIAI), vitamin D receptors, estrogen receptors and interleukin-6 (IL-6) which monitor bone mineral density and bone shape and structure[6].

Collagen type I considers the main component of the bone matrix. Sp1 binding site Polymorphism in the transcriptional control region of the COL1A1 gene causes alleles with a G-base at the Sp1 binding are defined as ' $\mathrm{S}$ ', while alleles with a T-base are defined as ' $\mathrm{s}$ '. Many studies have shown that patients with ' $\mathrm{s}$ ' allele are mostly have reduced BMD and osteoporotic fractures in several populations [7].

The aim of this work was to study the relationship between SP1 polymorphism in the collagen type 1 alpha 1 gene and the development of osteoporosis in patients with Beta thalassemia.

\section{SUBJECTS AND METHODS}

Study design and sample selection:

This study was conducted in the Outpatient Clinic of Hematology Unit of Pediatric Department and Clinical Pathology Department at Zagazig University Hospitals on 40 thalassemic patients at their regular followup visits and forty age- and sex-matched healthy children as a control group.

This study included 80 subjects, They were classified as the following:

\section{Group 1:}

This group included 40 patients (21 females $\& 19$ males) on follow up of $\beta$-thalassemia and they are undergoing blood transfusion and iron chelation therapy(desferal) which their ages ranged from 6-18 years and classified as:

Group 1A: 22 patients with $\beta$ - thalassemia major (TM).

Group 1B:18 patients with $\beta$ - thalassemia intermedia (TI).

\section{Group 2:}

This group included 40 apparently healthy subjects cross matched with age and sex.

An informed written consent of participation in the study was signed by the parents or legal guardians of the studied subjects. This study was approved by the Ethical Research Committee, Faculty of medicine, Zagazig University.

Each member of this research was admitted to complete history talking and full clinical observation and laboratory investigation as complete blood count done by sysmex $\mathrm{XN}, \mathrm{Hb}$ electrophoresis done by full automated capillary electrophoresis, Serum Calcium level, alkalin phosphatase done by Cobas 8000 , Bone Density by DEXA, Serum osteocalcine level and COLIAI gene polymorphism by using polymerase chain reaction - restriction fragment length polymorphism technique (PCR-RFLP).

\section{- Bone Density by DEXA:}

Bone mineral density (BMD) of the lumber spine (second, third and fourth lumber vertebrae) was measured by dual energy X-ray absorptiometry (DEXA). All children were scanned in the supine position, BMD data were expressed as grams per centimeter. Squared and were compared with BMD values of normal children of the same age. 
WHO measurement of osteoporosis using BMD measurement at the spine, hip or forearm:

\begin{tabular}{ll}
\hline Normal & $\begin{array}{l}\text { BMD is within 1 SD of a young normal adult (T-score at }-1.0 \\
\text { and above) }\end{array}$ \\
\hline Low Bone Mass (Osteopenia) & $\begin{array}{l}\text { BMD is between 1.0 and 2.5 SD below that of a young normal } \\
\text { adult (T-score between }-1.0 \text { and -2.5) }\end{array}$ \\
\hline Osteoporosis & $\begin{array}{l}\text { BMD is 2.5 SD or more below that of a young normal adult } \\
\text { (T-score at or below -2.5) }\end{array}$ \\
\hline Severe/Established Osteoporosis & $\begin{array}{l}\text { BMD is 2.5 SD or more below that of a young normal adult } \\
\text { (T-score at or below }-2.5), \text { plus there have been } \leq 1 \text { fractures }\end{array}$ \\
\hline
\end{tabular}

\section{DNA analysis}

DNA was extracted from leukocytes of peripheral blood samples using the QIAamp® UltraSens virus ${ }^{\circledR}$ extraction kit (Qiagen) USA according to manufacture protocol. The extracted cfDNA was stored at $-20^{\circ} \mathrm{C}$ till analysis.

\section{PCR amplification:}

DNA was amplified using Maxime PCR PreMix Kit composed of Ready- to- Go PCR Beads which are designed and manufactured by (iNtRON Biotechnology). PCR reaction with $25 \mu \mathrm{l}$ final volume was prepared by adding12.5ul Master mix, 1.0 $\mu 1$ Forward primer, $1.0 \mu 1$ Reverse primer, $10 \mu$ lextracted DNA and $0.5 \mu \mathrm{l}$ Sterile high quality water into PCR wells.

PCR was done by the following conditions: initial denaturation at $94^{\circ} \mathrm{C}$ for $3 \mathrm{~min}, 35$ cycles $\left(94^{\circ} \mathrm{C}\right.$ for $50 \mathrm{sec}$ for denaturation, $62^{\circ} \mathrm{C}$ for $10 \mathrm{sec}$ for annealing, $72^{\circ} \mathrm{C}$ for $15 \mathrm{sec}$ for extention) and for Final extention step $72{ }^{\circ} \mathrm{C}$ for 5 min.

The PCR products were stored at $-80^{\circ} \mathrm{C}$ until used.

\section{collagen type I alpha -1gene Primers: \\ Forward primer \\ GTCCAGCCCTCATCCTGGCC -3'). \\ Reverse \\ primer(5'- \\ TAACTTCTGGACTATTTGCGGACTTTTTG G $-3^{\prime}$ ).}

Detection of amplified PCR product by agarose gel electrophoresis:

$5 \mu \mathrm{l}$ of each sample were slowly loaded into sample well and $5 \mu \mathrm{l}$ PCR marker was also loaded into one of the wells.
The power supply was programmed as 150 volts and 100 milli amperes for 20 minutes (Consort E 844). Then The gel was placed on the filter area of the ultraviolet transilluminator (Biometra).

The amplified PCR product gave rise to $264 \mathrm{bp}$ fragment.

\section{Restriction digest reaction:}

The amplified DNA was digested by using (Bal 1)(BioLabs, UAS, part No. R0534S, 250 Units) $(5,000$ units/ml).

$10 \mu \mathrm{l}$ of amplified product added to $16 \mu \mathrm{l}$ sterile distilled water then add $2 \mu 1$ of restriction enzyme and $2 \mu 1$ of reaction buffer then incubated at $37^{\circ} \mathrm{C}$.

Detection of the band of polymorphism:

Then the digested segments were subjected to electrophoresis on eight percent non denaturing polyacrylamide gel; then the gel stained using ethidium bromide (one $\mathrm{mg} / \mathrm{ml}$ ) for thirty minutes at room temperature then followed by visualization by the ultraviolet (UV) transilluminator.

The mplified product 264 bp fragment with $\mathrm{Bal}$ 1 restriction enzyme gave rise to:

- Undigested 264bp fragment indicated the presence of $\mathrm{S}$ allele and identified as G-T substitution

- Appearance of 246bp fragment indicated the presence of $\mathrm{s}$ allele.

Thehomozygous variant SS $(\mathrm{G} / \mathrm{G})$ result in one fragment at $264 \mathrm{bp}$, homozygous variant ss $(\mathrm{T} / \mathrm{T})$ result in one fragment at 246bp while the heterozygous variant $\mathrm{Ss}(\mathrm{G} / \mathrm{T})$ result in two fragments at $264 \mathrm{bp}$ and $246 \mathrm{bp}$.

described in Fig. 1. 


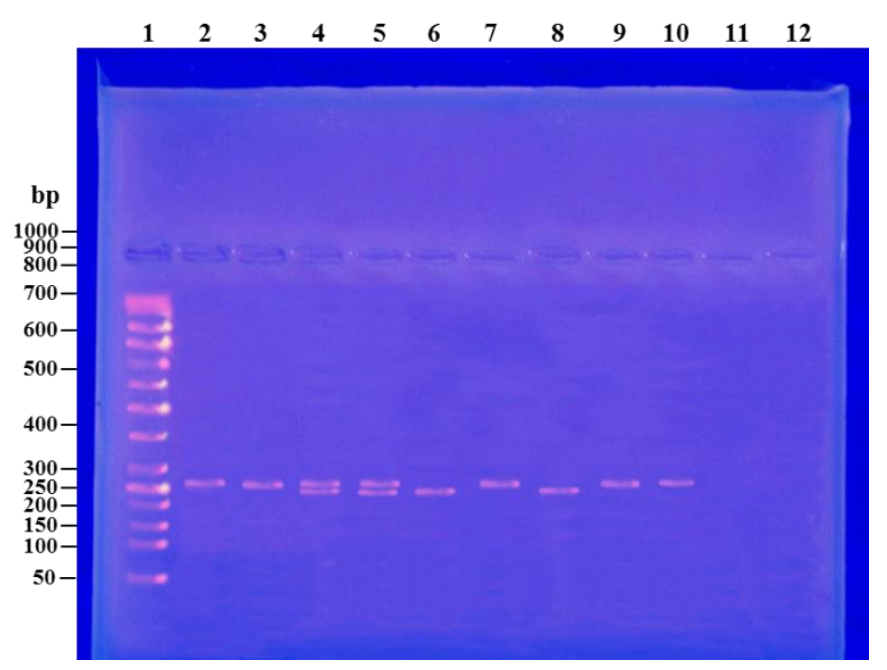

Fig. (1): A representation of collagen gene polymorphism by PCR-RFLP.

Lane 1: Ladder (50bp).

Lane2,3,7,9,10: represent the homozygouse cases (SS) genotype of collagen gene $(\mathrm{G} / \mathrm{G})$.

Lane 4,5: represent the heterozygouse cases (Ss) genotype of collagen gene (G/T).

Lane 6,8: represent homozygouse cases (ss) genotype of collagen gene (T/T).

\section{Statistical analysis:-}

For statistical analysis using statistical program SPSS version 10 for Windows (SPSS, Chicago, Illinois, USA).

Presentation of data in the form of median, frequency, percentages.
Comparing two independent groups using Mann-Whitney test (U). For comparing between independent proportions using Chi squared test $\left(\chi^{2}\right)$ and for non- parametric data using kruskal wallis test $(\mathrm{K})$.

$\mathrm{P}$ value $<0.05$ was considered statistically significant.

\section{RESULTS}

Table (1): Demographic data of the studied groups.

\begin{tabular}{|c|c|c|c|c|c|c|}
\hline Demographic data & \multicolumn{2}{|c|}{$\begin{array}{l}\text { Group } 1 \\
(n=40)\end{array}$} & \multicolumn{2}{|c|}{$\begin{array}{c}\text { Group } 2 \\
(n=40)\end{array}$} & Test & $\begin{array}{c}\text { p-value } \\
\text { (Sig.) }\end{array}$ \\
\hline$\frac{\text { Age (years) }}{\text { Mean } \pm \text { SD }}$ & \multicolumn{2}{|c|}{$10.50 \pm 2$} & \multicolumn{2}{|c|}{$10 \pm 1.9$} & $1.146^{\bullet}$ & $\begin{array}{l}0.255 \\
(\mathrm{NS})\end{array}$ \\
\hline Sex & No. & $\%$ & No. & $\%$ & & \\
\hline Male & 20 & $50.0 \%$ & 20 & $50.0 \%$ & $\Omega \cap \cap \cap \#$ & 1.000 \\
\hline Female & 20 & $50.0 \%$ & 20 & $50.0 \%$ & 0.000\# & $(\mathrm{NS})$ \\
\hline Family history & No. & $\%$ & No. & $\%$ & & \\
\hline Positive & 14 & $35 \%$ & 0 & $0 \%$ & $607 \pi$ & 0.000 \\
\hline negative & 26 & $65 \%$ & 40 & $100 \%$ & $10.9 / \#$ & $(\mathrm{HS})$ \\
\hline
\end{tabular}

- T-test

\# Chi-square test $\left(\chi^{2}\right)$.

$\mathrm{p}<0.05$ is significant.

Sig.: Significance. 
This table shows no significant difference between cases and controls as regard age $(\mathrm{p}=0.255)$ and sex $(\mathrm{p}=1.000)$. And highly significant difference in family history $(\mathrm{p}=0.000)$.

Table (2):Comparison between patients and control groups as regard onset and frequency of blood transfusion and duration of iron chelation.

Group 1a Group $\quad$ U Test $\quad$ p

1b

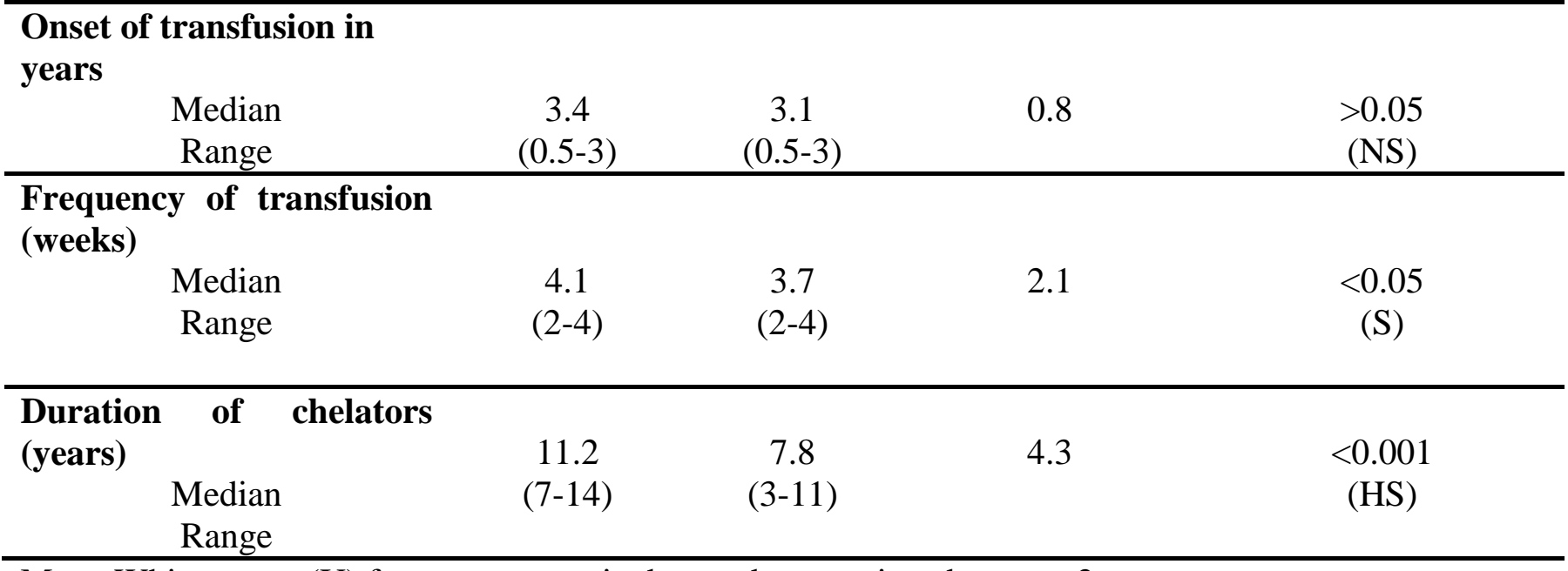

Mann Whitney test (U) for nonparametric data and comparison between 2 groups.

$\mathrm{p}<0.05$ is significant

It was found statistical significant variation and no significant differenceas regardonset of between 2 groups as regard frequency of blood frequency of blood transfusion.

transfusion and duration of chelation therapy

Table (3):Serum level of Calcium, Osteocalcin and Alkaline phosphatase in all studied groups.

\begin{tabular}{|c|c|c|c|c|c|}
\hline & $\begin{array}{c}\text { Group 1a } \\
\quad(\mathrm{n}=22)\end{array}$ & $\begin{array}{c}\text { Group 1b } \\
\quad(\mathrm{n}=18)\end{array}$ & $\begin{array}{c}\text { Group } 2 \\
(n=40)\end{array}$ & $\begin{array}{c}\text { K } \\
\text { Test }\end{array}$ & $\begin{array}{l}\text { p-value } \\
\text { (Sig.) }\end{array}$ \\
\hline \multicolumn{6}{|c|}{ Laboratory finding } \\
\hline \multicolumn{6}{|c|}{ calcium $(\mathrm{mg} / \mathrm{dL})$} \\
\hline Median & 8.78 & 8.96 & 10.96 & 39.7 & 0.000 \\
\hline Range & $(5.02-9.14)$ & $(5.2-9.32)$ & $(7.24-11.28)$ & & $(\mathrm{HS})$ \\
\hline \multicolumn{6}{|c|}{$\mathbf{O C}(\mathrm{ng} / \mathrm{mL})$} \\
\hline Median & 10.62 & 10.43 & 17.11 & 35.6 & 0.000 \\
\hline Range & $(6.12-11.92)$ & $(6.07-11.59)$ & $(5.45-25.57)$ & & $(\mathrm{HS})$ \\
\hline \multicolumn{6}{|c|}{$\operatorname{ALP}(\mathrm{u} / \mathrm{L})$} \\
\hline Median & 418.44 & 406.29 & 239.9 & 35.4 & 0.000 \\
\hline Range & (166.74-666.34) & $(182.25-626.53)$ & $(87.82-388.18)$ & & $(\mathrm{HS})$ \\
\hline
\end{tabular}

kruskalwallis test $(\mathrm{K})$ for non-parametric results and comparison between 3 groups.

- $\mathrm{p}<0.05$ is significant.

- Sig.: Significance.

- OC: Osteocalcin.

- ALP: Alkaline phosphatase. 
This table showed highly significant difference between thalassemia major and thalassemia intermedia compared to control group as regard $\mathrm{Ca}, \mathrm{OC}$ and ALP $(\mathrm{P}=0.000)$.

Table (4):Comparison between two groups of thalassemia (TM, TI) as regard Serum level of Calcium, Osteocalcin and Alkaline phosphatase.

\begin{tabular}{ccccc}
\hline Laboratory finding & $\begin{array}{c}\text { Group 1a } \\
(\mathbf{n = 2 2})\end{array}$ & $\begin{array}{c}\text { Group 1b } \\
(\mathbf{n = 1 8})\end{array}$ & $\begin{array}{c}\text { U } \\
\text { Test }\end{array}$ & $\begin{array}{c}\text { p-value } \\
(\text { Sig. })\end{array}$ \\
\hline $\begin{array}{c}\text { calcium }(\mathrm{mg} / \mathrm{dL}) \\
\text { Median } \\
\text { Range }\end{array}$ & $\begin{array}{c}\text { 8.78 } \\
(5.02-9.14)\end{array}$ & $\begin{array}{c}8.96 \\
(5.2-9.32)\end{array}$ & 163.50 & $0.346(\mathrm{NS})$ \\
\hline OC $(\mathrm{ng} / \mathrm{mL})$ & & & & \\
Median & 10.62 & 10.43 & 185.00 & 0.722 \\
Range & $(6.12-11.92)$ & $(6.07-11.59)$ & & $(\mathrm{NS})$ \\
\hline ALP $(\mathrm{u} / \mathrm{L})$ & 418.44 & 406.29 & 169.50 & 0.437 \\
Median & $(166.74-666.34)$ & $(182.25-626.53)$ & & $(\mathrm{NS})$ \\
Range & & & & \\
\hline
\end{tabular}

- Mann-whintey test (U).

- $\mathrm{P}<0.05$ is significant.

- $\quad$ Sig.: Significance.

This table revealed no significant difference regard calcium, osteocalcin and alkaline between two studied groups of thalassemia as phosphatase $(\mathrm{p}>0.05)$.

Table (5): DEXA finding concerning Bone Mineral Density and Z-score in the studied groups.

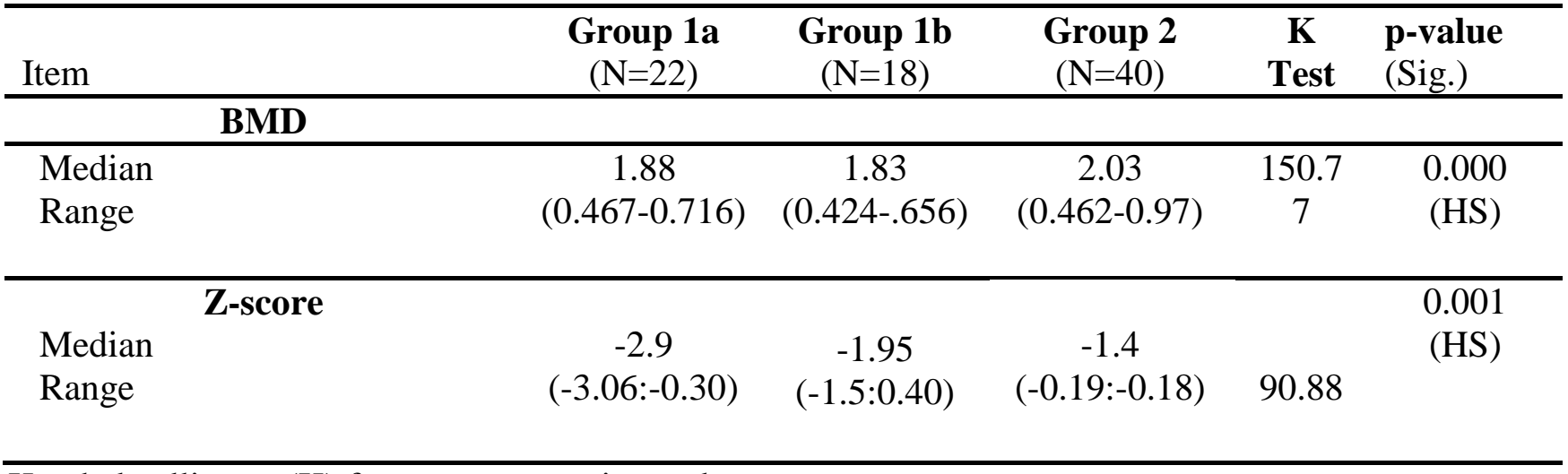

Kruskalwallis test (K) for non-parametric results.

$\mathrm{P}<0.05$ is significant.

Sig.: Significance.

DEXA: Dual-Energy X-ray Absorptiometry.

BMD: Bone Mineral Density.

This table showed highly significant difference between thalassemia major and intermedia compared to control group $(\mathrm{p}<.001)$. 
Table (6): DEXA finding concerning Bone Mineral Density and Z-score in thalassemic patients.

\begin{tabular}{llcccc}
\hline & Item & $\begin{array}{c}\text { Group 1a } \\
(\mathrm{n}=22)\end{array}$ & $\begin{array}{c}\text { Group 1b } \\
(\mathrm{n}=18)\end{array}$ & $\begin{array}{c}\text { U- } \\
\text { U Test } \\
\text { value } \\
\text { (Sig.) }\end{array}$ \\
\hline \multirow{2}{*}{ Median } & BMD & 1.88 & 1.83 & 2.63 & 0.012 \\
& Range & $\begin{array}{c}(0.467- \\
0.716)\end{array}$ & $(0.424-.656)$ & & \\
\hline \multirow{2}{*}{ Median } & Z-score & -2.9 & -1.95 & -5.132 & 0.000 \\
& Range & $(-3.06:-0.30)$ & $(-1.5: 0.40)$ & & \\
\hline
\end{tabular}

Mann-Whitney test (U).

$\mathrm{P}<0.05$ is significant.

Sig.: Significance.

This table showed significant difference between thalassemia major and intermedia as regard DEXA finding concerning BMD and Z-score.

Table (7): Correlation between Onset of transfusion, Frequency of transfusion, Duration of iron chelators and Serum level of Calcium, Osteocalcin, Alkaline phosphatase and DEXA.

\begin{tabular}{cccc}
\hline Item & $\begin{array}{c}\text { Onset of } \\
\text { transfusion } \\
\text { in years }\end{array}$ & $\begin{array}{c}\text { Frequency of } \\
\text { transfusion in } \\
\text { years }\end{array}$ & Duration of iron chelators \\
\hline Calcium & 0.7 & -0.25 & 0.05 \\
r coefficient & 0.03 & 0.8 & 0.6 \\
P-value & $(\mathrm{S})$ & $(\mathrm{NS})$ & $(\mathrm{NS})$ \\
\hline OC & 0.6 & -0.05 & 0.39 \\
r coefficient & 0.01 & 0.6 & 0.7 \\
P-value & $(\mathrm{S})$ & $(\mathrm{NS})$ & $(\mathrm{NS})$ \\
\hline ALP & 0.8 & 0.33 & -0.4 \\
r coefficient & 0.04 & 0.4 & 0.75 \\
P-value & $(\mathrm{S})$ & $(\mathrm{NS})$ & $(\mathrm{NS})$ \\
\hline DEXA & 0.7 & -0.2 & 0.05 \\
r coefficient & 0.02 & 0.3 & 0.6 \\
P-value & $(\mathrm{S})$ & $(\mathrm{NS})$ & $(\mathrm{NS})$ \\
\hline
\end{tabular}

$\mathrm{P}<0.05$ is significant.

Sig: Significance. 
This is table illustrates:

- Positive correlation between onset of transfusionand laboratory finding (calcium, osteocalcin and ALP) and DEXA ( $\mathrm{p}<0.05)$.It denotes the earlier onset of blood transfusion the less decrease in calcium and osteocalcin

levels and DEXA. And the less increase of alkaline phosphatase level.

- No significant correlation betweenfrequency of transfusion, duration of iron chelation and laboratory finding (calcium, osteocalcin and ALP) and DEXA.

Table (8): Distribution of COLIA1 genotype in thalassemic patients and healthy control.

\begin{tabular}{|c|c|c|c|c|c|c|c|c|}
\hline \multirow[b]{3}{*}{ COLIA1 genotype } & \multicolumn{6}{|c|}{ Total $(\mathrm{N}=80)$} & \multirow[t]{3}{*}{$\chi^{2}$ Test } & \multirow{3}{*}{$\begin{array}{l}\text { p- } \\
\text { value } \\
\text { (Sig.) }\end{array}$} \\
\hline & \multicolumn{2}{|c|}{$\begin{array}{c}\text { Group 1a } \\
(\mathrm{n}=22)\end{array}$} & \multicolumn{2}{|c|}{$\begin{array}{r}\text { Group 1b } \\
(\mathrm{n}=18)\end{array}$} & \multicolumn{2}{|c|}{$\begin{array}{c}\text { Group } 2 \\
(\mathrm{n}=40)\end{array}$} & & \\
\hline & No. & $\%$ & No. & $\%$ & No & $\%$ & & \\
\hline Homozygous 264(SS) & 10 & $30.7 \%$ & 8 & $49.4 \%$ & 25 & $79.5 \%$ & \multirow{3}{*}{10.02} & \multirow{3}{*}{$\begin{array}{c}.040 \\
(\mathrm{~S})\end{array}$} \\
\hline Heterozygous 264+246(Ss) & 9 & $55.63 \%$ & 10 & $50.6 \%$ & 15 & $20.5 \%$ & & \\
\hline Homozygous 246(ss) & 3 & $13.67 \%$ & 0 & $0 \%$ & 0 & $0 \%$ & & \\
\hline
\end{tabular}

Chi-square test $\left(\chi^{2}\right)$.

$\mathrm{p}<0.05$ is significant.

Comparison of COLIA1 genotyping in patients with $\beta \mathrm{TM}, \beta \mathrm{TI}$, healthy group showed highly significant difference in which $\beta \mathrm{TM}$ had $30.7 \%$ Homozygous (SS), 55.63\%Heterozygous
(Ss) and 13.67\%Homozygous (ss) and $\beta$ TI had $49.4 \%, 50.6 \%, 0 \%$ compared to control group $(\mathrm{p}=.012)$.

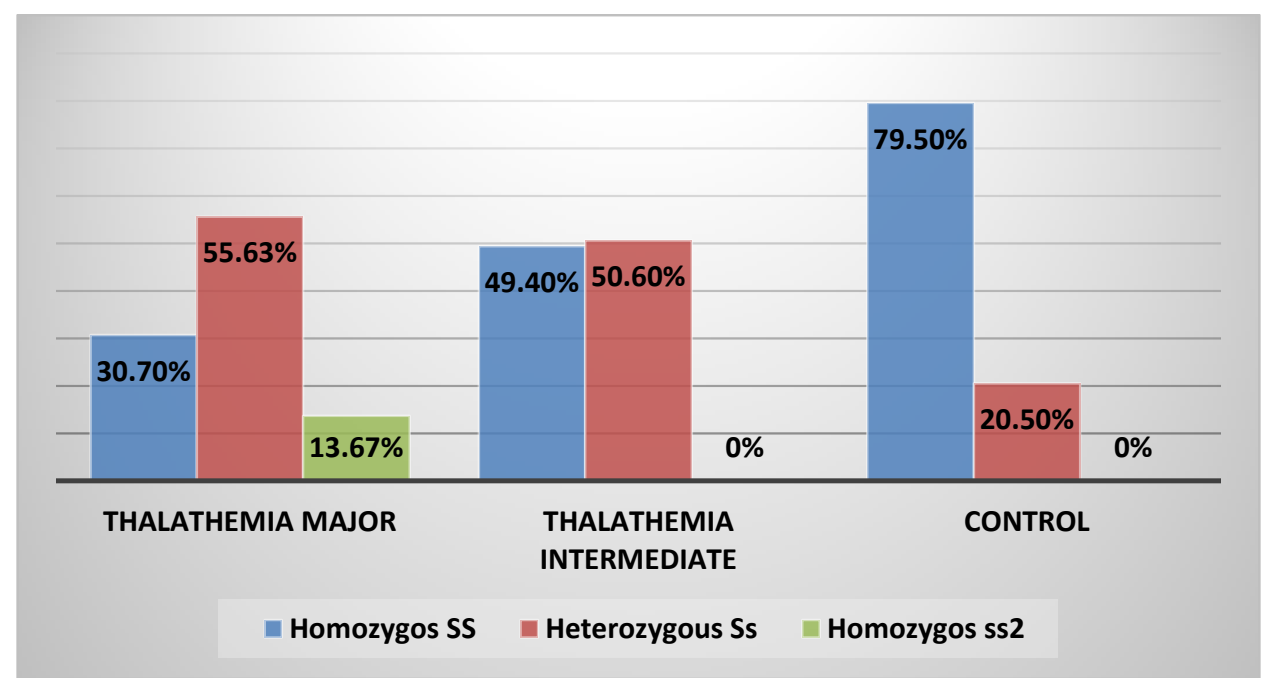

Figure (2): Distribution of COLIA1 genotype in thalassemic patients and healthy control.

Multiple bar chart showed high percentage of Ss, ss genotype in thalassemia major $(55.63 \%$,
$13.67 \%)$ than thalassemia intermedia $(50.60 \%$, $0 \%$ ) compared to control group. 
Table (9): Comparison between Thalassemia major and Thalassemia intermedia as regard COLIA1 genotype.

Item

\begin{tabular}{cccc}
$\begin{array}{c}\text { Group 1a } \\
(\mathrm{n}=22)\end{array}$ & $\begin{array}{c}\text { Group 1b } \\
(\mathrm{n}=18)\end{array}$ & $\chi^{2}$ Test & $\begin{array}{c}\text { p-value } \\
(\text { Sig. })\end{array}$ \\
\hline no & no $\%$ & $\%$ &
\end{tabular}

\begin{tabular}{|c|c|c|c|c|c|c|}
\hline Homozygous SS genotype & 19 & $30.7 \%$ & 8 & $49.4 \%$ & & \\
\hline Heterozygous Ss genotype & 9 & $55.63 \%$ & 10 & $50.6 \%$ & \multirow{2}{*}{2.904} & \\
\hline Homozygous ss genotype & 3 & $13.67 \%$ & 0 & $0 \%$ & & \\
\hline
\end{tabular}

Chi-square test $\left(\chi^{2}\right)$.

$\mathrm{p}<0.05$ is significant.

This table showed no significant difference between two types of beta thalassemia in SP1 polymorphism in the collagen type I alpha -1 (COLIA1). There was three cases with homozygous ss genotype of collagen gene that associated with low calcium level, low osteocalcin level, high alkaline phosphatase level and low DEXA finding concerning BMD and Z-score.

Table (10): Relation between COLIA1 genotype distribution and laboratory data, DEXA among studied groups.

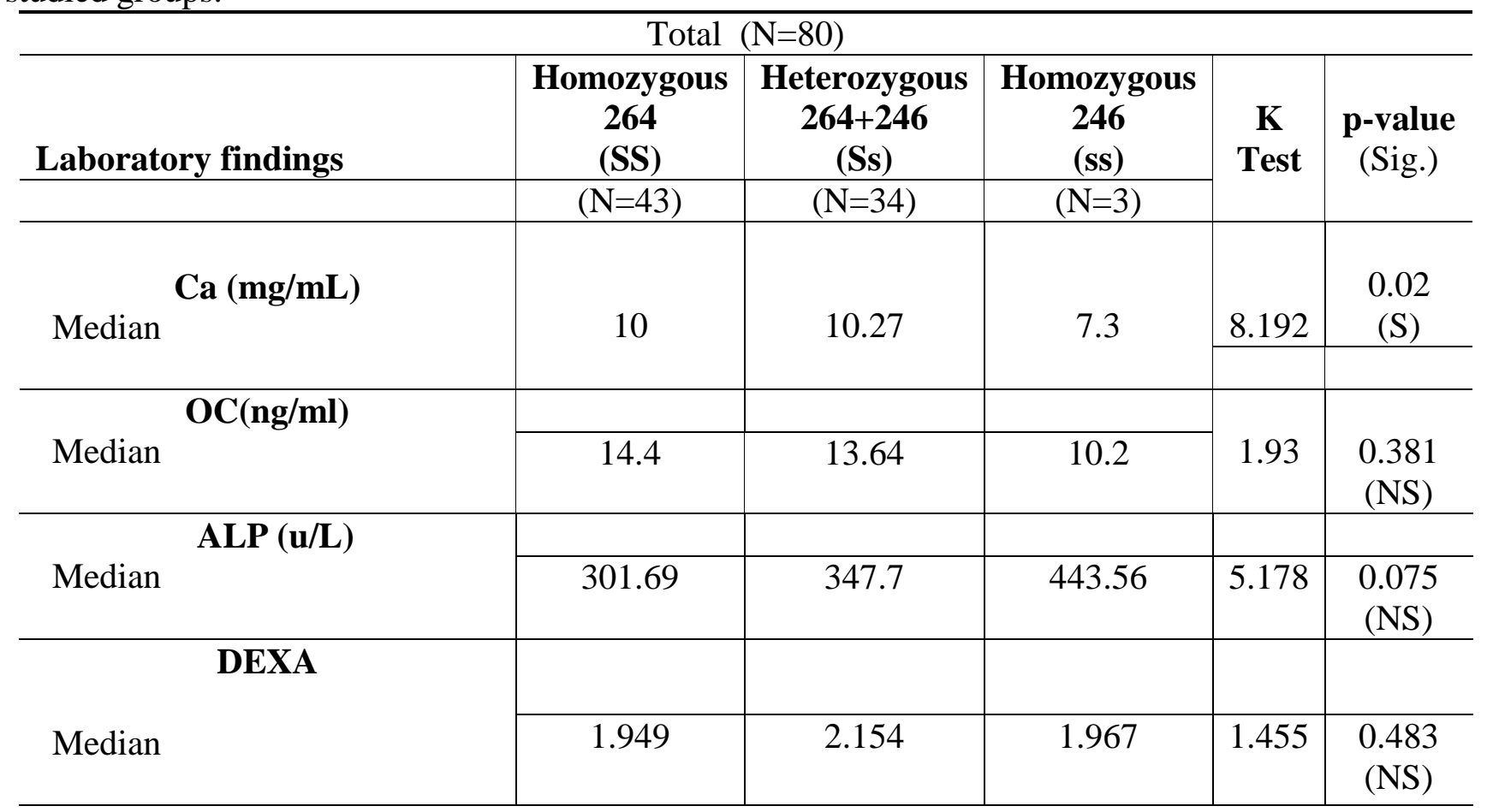

Kruskal Wallis Test (K)

$\mathrm{p}<0.05$ is significant 
Test showed significant relation between COLIA1 genotype and Calcium level and no significant relation between COLIA1 genotype and alkaline phosphatase, osteocalcin level and $\operatorname{DEXA}(\mathrm{p}>0.05)$.

\section{DISCUSSION}

In $\beta$ - thalassemia, low bone mass represents a chronic, degenerativedisease, even betweengood transfused and iron chelated prepubertal and adult cases [8]. The inheritance of bone mass is affectedgeneticeffect, although the genes responsible for bone mass are lessreported[9].New researches showed the relation between Sp1polymorphism at first intron of collagen one gene and bone thickness in many people[10],[11].

Our result has been analyzed to detect the relationship between SP1 polymorphism in the collagen type 1 alpha 1 gene and the development of osteoporosis in patients with $\beta$ thalassemia

The present study detected significant variation betweenTM,TI groups as regards frequency of blood transfusion and duration of iron chelation $(p<0.05)$ although it thought that absence significant variation between them as regard onset of blood transfusion.

Our data showed significant hypocalcaemia which was $100 \%$ in $\mathrm{TM}$ and $55.5 \%$ in $\mathrm{TI}$ compared to control group $25 \%$.

In agreement with our data that reported biochemical hypocalcaemia in beta thalassemia patients [12],[13],[26],[15],[16].

In contrast, there was no difference in plasma level of calcium in thalassemic patients compared with healthy control subjects [17].

Our result showed the low level of serum osteocalcin and high alkaline phosphatase in beta thalassemic patients than healthy control. Although there is absence significant variations between TM, TI as regard calcium, osteocalcine and alkaline phosphatase $(\mathrm{p}<0.05)$.

Low level of serum osteocalcin and high alkaline phosphatase in thalassemic patients were observed in several studies [18],[19],[17],[14],[20].

In contrast with current study, there was no statistically significant variations in alkaline phosphatase levelsofblood

transfusion dependent TMcases [21].

In the present study, there was significantly lower BMD and Z-score values in patient groups than controls both at the lumbar and femoral levels $(\mathrm{p}<0.001)$ which is highly significant. Alsoit found significant variations between TM, TI ( $\mathrm{p}$ value less than 0.05 ).

Several previous studies showed lower BMD in thalassemic patients [22],[23],[24],[25],[26]which due to their low physical improvement which affected by iron overload and iron chelation that can affect the liver and the endocrine system.

In contrary to our result, Christoforidis et al. [27] reported that BMD Z-scores were within normal.

In the present study, the SS genotype $(G / G)$ in $\beta \mathrm{TM}$, $\beta$ TIand control was $30.7 \%, 49.4 \%$, $79.5 \%$ respectively. The Ss genotype $(G / T)$ in $\beta \mathrm{TM}, \beta \mathrm{TI}$ and control was $55.63 \%, 50.6 \%$, $20.5 \%$ respectively. The ss genotype $(T / T)$ in $\beta$ TM was $13.67 \%$ only. The difference was statistically significant $(\mathrm{p}=0.012)$.Identifying the frequency of alleles in $\beta$-thalassemia persons and health persons, it was found that the s allele higher in the TM $(13.7 \%)$ than TI and control. The low percentage of ss genotype in thalassemic personsmaydue to the limited size ofthe examined group or caused by ethnic cause.It was found absenceof significant variation between TM, TI inCOLIAI genotype ( $>0.05$ ).

Singh et al. [7]reported in his study that SP1 polymorphism in $\beta$-thalassemia, $19 \%$ of $\beta$-TM patients have SS $(G / G)$ genotype, $40 \%$ have Ss $(G / T)$ and $43 \%$ have ss $(T / T)$.And Kritanjali et al. [13] $19.8 \%$ SS $(G / G), 35.8 \%$ Ss $(G / T)$ and $43.4 \%$ ss $(T / T)$ with $37.7 \% \mathrm{~S}, 61.3 \%$ s allelic frequencies in TM persons.

Galal et al. [6] reported that $80.6 \%$ of the $\beta$ thalassemia patients were homozygous for SS $(G / G)$ and $19.4 \%$ were heterozygotes for Ss $(G / T)$ polymorphism. Guzeloglu et al. [28] revealed that there was no ss genotype. There was Ss, SS and ss genotypes in $24.3 \%, 40.5 \%$ and $35.2 \%$ of patients, and in $16 \%, 84 \%$ of the control group, respectively. Also Arisal et al. 
[9] detected that $64.3 \%$ Ss $(G / T)$ and $35.7 \%$ SS $(G / G)$ in $\beta$-TM. $60 \%$ Ss $(G / T)$ and $40 \%$ SS $(G / G)$ in $\beta$-TI which was significantly higher compared to control group $(\mathrm{p}=0.029)$.

In a study done by Perrota et al. [29], the genotypes of Ss and ss were accompanied by low bone mineral density than SS genotype. The absent relation between bone mineral density and COLIAI polymorphism in thalassemic persons due to low frequency of the s allele, also the low sample size. And BMD is to be detected by a manypolygenic and acquired factors, and its inheritance is due to be under polygenic effect [30].

Jin-Ai et al. [31] reported that collagen gene one alpha one genotype diagnosebone fracture by techniquesthat are partly nondependent of bone mineral density and revealed high risk of osteopenic fracture in relation to SP1 transcription factor polymorphism although of mild relation with bone mineral density. There was a study revealed absent correlation between SP1/BMD in TM patients had low bone mass [32].

Limitations of the study were that a small number of thalassemic patients were evaluated.

\section{CONCLUSION}

The frequency of low Bone Mineral Density (BMD) and osteoporosis are high among the children with $\beta$ - Thalassemia and SP1 mutation is one of the factors that influences bone density in these patients with no significant difference between thalassemia major and intermedia. The findingsincrease the rolewhich genotyping at SP1 site may consider an important cause for detecting the thalassemic persons with a risk of achieve osteoporosis and bone fractures thataccount a possible role for improvement of osteoporosis management in those thalassemic persons.

Conflict of interest:- The authors have no conflict of interest to declare.

\section{REFERANCES}

[1] Hapgood G, Walsh T, Cukierman R, Paul E, Cheng K, Bowden DK. Erythropoiesis is not equally suppressed in transfused males and females with $\beta$-thalassemia major: are there clinical implications? .Haematologica2015; 100 (8): 292-294.

[2] Carlo Perisano, EmanueleMarzetti, Maria Silvia Spinelli, Cinzia Anna Maria Callà, CalogeroGraci,

GiulioMaccauro. Physiopathology of Bone Modifications in Thalassemia, Anemia2012; 5:68-77.

[3] Zhang J, Ai Z, Ning X, Liu X, Tang W, Luo Y. The Association between Vitamin D Receptor FokI Gene Polymorphism and Osteoporosis in Postmenopausal Women: A Meta-Analysis. $J \quad$ OsteoporPhys Act2015;3:143.

[4]MaheshChandMeena,AlokHemal, MukulSatij a, ShilpaKhannaArora, and ShahinaBano. Comparison of Bone Mineral Density in Thalassemia Major Patients with HealthyControls.Advances in Hematology2015; 4.

[5] Kostik MM, Smirnov AM, Demin GS, Mnuskina MM, Scheplyagina LA, Larionova VI.Genetic polymorphisms of collagen type I a1 chain (COL1A1) gene increase the frequency of low bone mineral density in the subgroup of children with juvenile idiopathic arthritis. EPMA J 2013; 4(1):1-8.

[6] Galal A, Hanan M. Hameda, Mona E.L. Ghamrawyb,Abd El Azeem K, Hussein IR, Mona Fayez Abd-Elgawad MF. An SP1binding site polymorphism in the COLIAI gene and osteoporosis in Egyptian patients with thalassemia major.Blood Coagulation and Fibrinolysis2011; 22:81-85.

[7] Singh K, Agarwal S, Gupta S . An SP1binding site polymorphism in the COLIAI gene: may be a strong predictor for low bone density in thalassemia major. Gene TherMolBiol 2013; 15:112-119.

[8] Tantawy AA, El Kholy M, Moustafa T, Elsedfy HH. Bone mineral density and

calcium metabolism in adolescents with betathalassemia major. PediatrEndocrinol 2008; 6 (1 suppl):132-135

[9] Arisal O, Deviren A, Fenerci EY, Hacihanefioglu S, Ulutin T, Erkmen S, et al.Polymorphism analysis in the COLIA1 gene of patients with thalassemia major and intermedia. HaematologiaBudap2002;32:475482.

[10] Grant SF, Reid DM, Blake G. Reduced bone density osteoporosisassociated with a 
polymorphic Sp1 binding site in the collagen type a1 gene. Nat Genet 1996; 14:203-205.

[13]Goyal M, Abrol P,Lal H. Parathyroid and calcium status in patients with thalassemia.Indian $\quad J \quad$ ClinBiochem2010;25: 385-387.

[11] Ji GR, Yao M, Sun CY, Zhang L, Han Z. Association of collagen type Ialpha1 (COLIA1) Sp1 polymorphism with osteoporotic fracture inCaucasian postmenopausal women: a meta-analysis. $J$ Int Med Res 2009;37:1725-1732.

[12] Bandebuche S, SagarV ,Sontakk A. Serum total Calcium level in patients with Thalassemia. International Journal of Medical Researchand Review2013; 1(4):190-192.

[13] Kritanjali Singh, SaritaAgarwal, Sushil Gupta.An SP1-binding site polymorphism in the COLIAI gene: may be a strong predictor for low bone density in thalassemia major.Gene Therapy and Molecular Biology2013; 15,112-119.

[14]Saboor Muhammad, Qudsia Fatima, QamarKhansa,

MoinuddinMoinuddin.Levels of Calcium, Corrected Calcium, Alkaline Phosphatase and Inorganic Phosphorus in Patients' Serum with $\beta$-Thalassemia Major on Subcutaneous Deferoxamine.J HematolThromb Dis2014; 2(2):2329-8790.

[15] Shah S.Assessment of serum calcium and phosphorus levels among transfusiondependent $\beta$ eta thalassemia major patients on chelation therapy. J Postgrad Med Inst 2015; 29(3): 168-171.

[16] SultanS, Syed Mohammed Irfan, Syed Ijlal Ahmed.Biochemical Markers of Bone Turnover in Patients with $\beta$-Thalassemia Major. Advances in Hematology 2016;

avaliable at http://dx.doi.org/10.1155/2016/5437609.

[17] Morabito N, Gaudio A, Lasco A, Atteritano M, Pizzoleo MA, Cincotta M, La RosaM, Guarino R, Meo A, Frisina N.Osteoprotegerin and RANKL in the pathogenesis of thalassemia-induced osteoporosis: new pieces of the puzzle. $J$ Bone Miner Res2004;19:722-727.

[18] Asif M, Manzoor Z, Farooq MS,Kanwal A, Shaheen U, Munawar SH, et al. Correlation between serum ferritin level and liver function tests in thalassemic patients receiving multiple blood transfusions. Int J Res Med Sci2014; 2(3): 988-994.

[19] DundarUmit, KupesizAlphan, OzdemSebhat,GilgilEradl, TuncerTiraje, YesilipekAkif, et al. Bone metabolism and mineral density in patients with betathalassemia major. Saudi Med J2007; 28(10):1425-1429.

[20] Salama OS, Al-Tonbary YA, Shahin RA, Eldeen OA. Unbalanced bone turnover in children with beta-thalassemia. Hematology 2006; 11: 197-202.

[21] Goyal M, Abrol P,Lal H. Parathyroid and calcium status in patients with thalassemia. Indian J ClinBiochem2010;25: 385-387.

[22] AyferGozuPirinccioglu, VeysiAkpolat, OrhanKoksal,KenanHaspolat, Murat Soker. Bone mineral density in children with betathalassemia major in Diyarbakir.Bone2011;49(4):819-823.

[23]DomrongkitchaipornSomnuek,VorachaiSiri kulchayanonta,PantepAngchaisuksiri,Wasa naStitchantrakul,ChavasakKanokkantapon g, RajataRajatanavin. Abnormalities in Bone Mineral Density and Bone Histology in Thalassemia. Journal of Bone and Mineral Research 2003;18(9): 1682-1688.

[24] FouziaIshaq ,Asma Anwar ,MazherIqbal.Frequency of Low Bone Mineral Density and Osteoporosis in Children with Beta Thalassemia Major.P J M H S. 2015; 9 (3): 1073.

[25]MehranKarimi, AlirezaFotouhiGhiam, AlirezaHashemi,Saied Alinejad, MahmoodSoweid, Sara Kashef.Bone Mineral Density in Beta-Thalassemia Major and Intermedia.Indian Pediatrics 2007; 44: 29-31.

[26]RashidMerchant,AmishUdani,ViplaPuri,Val entinaD'cruz,Deepak

Patkar,AartiKarkera.Evaluation of Osteopathy in Thalassemia by Bone Mineral Densitometry and Biochemical Indices.Indian J Pediatr 2010; 77:987-991.

[27] Christoforidis A, Kazantzidou E, Tsatra I,Metaxa MA.Normal lumbar bone mineral density in optimally treated children and young adolescents with B-thalassemia major.Hormones 2007; 6: 334-340.

[28] Guzeloglu-Kayisli O, Cetin Z, Keser I, Ozturk Z, Tuncer T. Relationship between Sp1 polymorphism, osteoporosis in b 
thalassemia major patients. PediatrInt2008; 50:474-476.

[29] Perrotta S, Cappellini MD, Bertoldo F. Osteoporosis in b-thalassemia major

patients: analysis of the genetic background. $\mathrm{Br} \mathrm{J}$ Haematol 2000;111:461-466.

[30] Mahachoklertwattana P, Chuansumrit A, Sirisrio R, Choubtum L,Sriphrapradang A. Bone mineral density, biochemical and hormonalprofiles in suboptimally treated children and adolescents with betathalassemiadisease. ClinEndocrinol 2003; 58:273-279.
[31] Jin-Ai Mary Anne Tan, Ping-Chin Lee, Yong-Chui Wee, Kek Heng Chua. High Prevalence of Alpha- and Beta-Thalassemia in the adazandusuns in East Malaysia: Challenges in Providing Effective Health Care for an Indigenous Group. Journal of Biomedicine and Biotechnology 2010; available at: http://dx.doi.org/10.1155/2010/706872.

[32] Gaudio A, Morabito N, Xourafa A, CurroM, Czccamo D, Ferlazzo N, et al. Role of genetic pattern on bone mineral density in thalassemic patients. ClinBiochem 2010; 43:805-807. 